\title{
MLH1 Negative
}

National Cancer Institute

\section{Source}

National Cancer Institute. MLH1 Negative. NCI Thesaurus. Code C162307.

An indication that expression of MLH1 has not been detected in a sample. 